\title{
MENTAL COMFORT OF POLISH AGRICULTURAL PRODUCERS (PARTICIPATING IN FADN) AS A PART OF SUSTAINABILITY INDICATOR
}

\author{
Anna Kloczko-Gajewska ${ }^{1}$, Ph.D.; Piotr Sulewski ${ }^{2}$, Ph.D. hab. \\ ${ }^{1,2}$ Faculty of Economic Sciences, Warsaw University of Life Sciences - SGGW, Poland
}

\begin{abstract}
The research on social dimension of sustainability is rather underdeveloped when it comes to farms. This paper contains presentation and assessment of parameters describing mental comfort of Polish farmers participating in FADN. Basing on the representative sample of 600 farmers, we concluded that the distribution of mental comfort index was close to normal. The index of mental comfort and the index of living conditions were not correlated, but we could observe low, positive correlations between the index of mental comfort and the economic size of the farm. According to the survey, the farmers are rather overworked. They feel less stress when they can manage the risk and more when they have No influence on the situation. About 1/3 feel frustrated because they do not understand some of the law regulations concerning their type of activeness. The level of mental comfort was positively correlated with the level of education of the respondents.
\end{abstract}

Key words: sustainability indicators, social sustainability, farms, FADN sample, Poland.

JEL code: Q01, Q12, I31.

\section{Introduction}

Sustainable development and sustainability at various levels have been a problem addressed by scientists of many specialisations as well as policymakers for decades. The interest in this topic burst out in the late 1980s after the Brundtland report was published (World Commission..., 1987), but its history is much longer (Spindler, 2013), (Vehkamaki, 2005). In the common sense, sustainability is usually associated with access to or preserving natural resources (clean air and water, energy resources, fertile soil etc.). Concentrating on the natural resources, preservation implicates that quite often sustainability is understood as being environmentally friendly, putting less stress on the social issues (Bebbington and Dillard, 2009, cited after Galdeano-Gomez, Perez-Mesa and Godoy-Duran, 2016). We should remember, however, that the aims of development are always social, and they should be reached with the consideration of environmental impact and economic feasibility (Sachs, 2011). Although we believe that real sustainability can be achieved only when all of the dimensions (namely: environmental, economic, and social) are considered - according to the "strong sustainability" concept (Pearce, 1993), (Thompson, 2007) - in this paper we would like to focus only on the social issues.

The indicators of social sustainability are quite often used in the research at national level (for example Raczkowska (2017) or Mikula (2016) writing about social inclusion) or at regional and local level (Wykluczenie, 2006; (Mikula, 2017), but they are rather underdeveloped at the level of particular economic units. Farming is a specific type of economic activity, where there is No clear division between a business unit and a family (Lowrance, Hendrix, and Odum, 1986). Thus, "the motivations of family farmers often go far beyond profit maximization, and encompass social and ecological aspects that will benefit their community" (Galdeano-Gomez, Perez-Mesa and Godoy-Duran, 2016, p. 352). At the same time, the production process is very much dependent on the climatic conditions and soil quality; this is why it is quite natural that the researchers dealing with sustainability in farming concentrate mostly on the environmental issues (Balbi et al., 2015; Reytar, Hanson and Henninger, 2014). There are some analyses that focus on the social dimension of sustainability in farming (Campbell et al., 2004; Bacon et al., 2011; GaldeanoGomez, Perez-Mesa and Godoy-Duran, 2016), but according to Latruffe et al. (2016), social sustainability of farms (and, more broadly, of agriculture) is the dimension that would need the most development of 
indicators in the future. It is still much easier to find theoretical frameworks or assessment tools than publications containing research results on this topic (Hennessy et al., 2013).

We should be aware of the fact that "farmers make land-use decisions not only in a business context but also in a personal context (...). It relates to individual and social conditions in which the farmer operates, including personal capabilities such as knowledge, skills and power, and attitudinal and psychological dimension." (Greiner R., 2015, p.155). Consequently, their influence on both economic development and natural environment is affected also by their understanding of the surrounding conditions (law regulations, economic mechanisms etc.), and by the level of stress they have to face. This is why, while describing social dimension of sustainability, we have used (among many others) indicators of the farmers' mental comfort. The aim of this paper was to describe and assess different aspects of mental comfort of agricultural producers participating in Polish FADN, as well as the relationships between the mental comfort indicator and chosen farm and farmers' characteristics.

\section{Methods}

The research ${ }^{3}$ was based on the database of Polish FADN 4 (Farm Accountancy Data Network), with additional data obtained through face-to-face structured interviews with farmers. Our sample consists of 600 farms participating in the Polish FADN system. They were selected using a layer/random selection procedure (Neyman, 1934; FADN, 2008; Was A., 2013) considering their representativeness in specialisation of production, standard output, and region. Given that the applied layer-random sampling method reflects the structure of farms in the population surveyed by FADN, we can assume that it is representative for the population of farms being in scope of observation of the Polish FADN. The interviews with farmers were conducted in 2017 by advisers from regional extension centres, who coordinated the collection of data within the FADN system. The data from interviews was added to relevant data available in the FADN database.

\section{Research results}

During the analyses we have assumed that sustainability has three dimensions: economic (on a farm understood as economic potential and production potential), environmental (environmental perception and correctness of agricultural practice), and social (living conditions and mental comfort).

In this paper, only the mental comfort indicator will be described in more details. We assumed that mental comfort of the farmers depends on the following issues: social status; health; free time and workload; stress; education and usefulness of knowledge; and ability to obtain neighbourhood helps. Table 1. shows that in the sample, among all the empirical maximums, the indicator of mental comfort was the lowest of all partial indicators, while the standard deviation was the smallest.

\footnotetext{
3 The research is a part of project financed by "National Science Centre, Poland" no. 2015/19/B/HS4/02273 (Measuring relative performance of farms representing a different level of conformance with Sustainable Development).

4 The FADN database in Poland covers 12.1 thousand respondents representing 730 thousand farms whose standard production value exceeds 4 thousand euro, that is it covers only commercial farms.

5 The remaining partial indicators were constructed basing on the following variables: economic potential - property, labour productivity, production value, agricultural area, work profitability, return on capital, stability of income, independence of income from financial support, financial independence; production potential - soil quality, risk of water and wind erosion, water conditions, content of nutrients in soil, soil acidification, natural sites; environmental perception - impact of agriculture on the environment, knowledge about the concept of sustainable agriculture, environmental requirements; correctness of agricultural practice in plant production - soil examination, parameters of chemical plant protection, the basis for determining the mineral fertilisation dose, incorporating manure, catch crops, rules for plant selection, agri-environmental programmes, the basis for the decision on the chemical plant protection treatment, correctness of the use of sprayer, incorporation of straw, prevention of loss of water from soil, seeds; correctness of agricultural practice in animal production - conditions in the livestock building, slipperiness of floors, aggressiveness of animals, separated pens, disinfection of rooms, intensity of animal production - conditions in the livestock building, slipperiness of floors, aggressiveness of animals, separated pens, disinfection of rooms, intensity of stocking; living conditions - sewage system, gas system, location, housing conditions.
construction of all these variables can be found in (Sulewski, Kloczko-Gajewska 2018).
} 


\section{Basic characteristics of partial indicators (sub-dimensions) (theoretical range of} variability $0-1$ )

\begin{tabular}{|c|c|c|c|c|c|c|c|}
\hline \multirow[b]{2}{*}{ Parameter } & \multicolumn{7}{|c|}{ Partial indicators } \\
\hline & 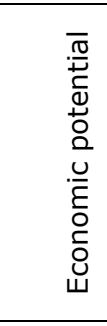 & 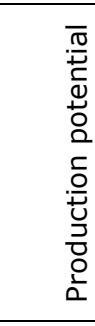 & 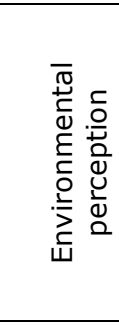 & 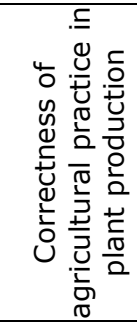 & 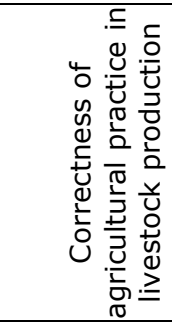 & 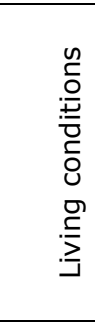 & $\begin{array}{l}\frac{t}{0} \\
\stackrel{0}{E} \\
0 \\
0 \\
\frac{0}{0} \\
\frac{1}{0} \\
\Sigma\end{array}$ \\
\hline empirical minimum & 0.07 & 0.05 & 0.06 & 0.05 & 0.26 & 0.24 & 0.20 \\
\hline empirical maximum & 0.92 & 0.93 & 1.00 & 0.97 & 0.99 & 1 & 0.77 \\
\hline mean & 0.51 & 0.50 & 0.67 & 0.51 & 0.61 & 0.61 & 0.53 \\
\hline Standard deviation & 0.20 & 0.18 & 0.19 & 0.17 & 0.15 & 0.15 & 0.09 \\
\hline
\end{tabular}

Source: authors' research

In order to describe the farmers' social status the respondents were asked to self-assess their affluence, in comparison with the rest of the village inhabitants (Figure 1).

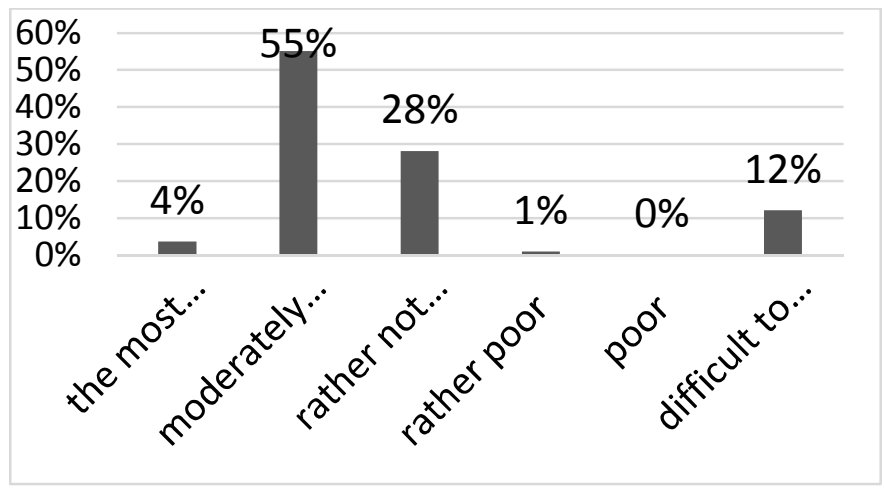

\section{Source: authors' research}

Fig. 1. How would you describe your financial situation in comparison to the rest of the village inhabitants?

A bit more than half of the farmers described themselves as "moderately affluent", 28 \% as "rather not affluent", and almost $4 \%$ as "the most affluent", while $12 \%$ had problems with this assessment.

We were not able to check the health status of the respondents, but we think that for mental comfort a subjective opinion could me more important, than the actual state. When asked about their health, 3/4 of the farmers described it as „rather good”, while approximately $9 \%$ as „rather bad”, and similar amount as "very good". Just few respondents chose "very bad".

Free time and workload were assessed with the use of few different parameters. The first of them was a subjective feeling of being overloaded with work on a farm and following it stress (Figure 2).

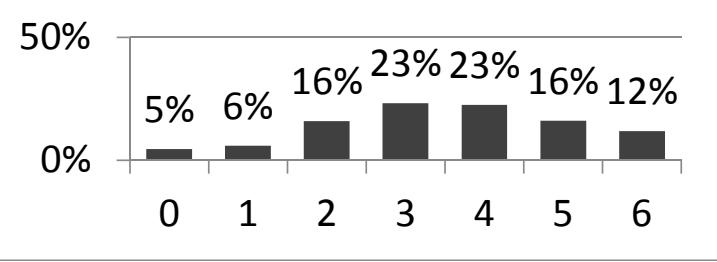

Source: authors' research

Fig. 2. How often do you feel overloaded with work on a farm and following it stress? (0- not at all, 6 - very often)

It is visible that the two highest marks were given by $28 \%$ respondents, while two lowest marks by $10 \%$ of them, which suggests that farmers are quite often overworked and under stress. As many as $70 \%$ 
of the respondents faced during last two years a situation, when they seriously delayed agricultural operations on their farm. In $3 / 4$ of the cases the reason was unfavourable weather, but in $15 \%$ it was caused by work overload on the farm, in $6 \%$ off-farm job, and in $7 \%$ - health problems.

To understand the problem of work overload more deeply, we have asked if the famers had enough time for sleep and rest, going out, deepening their knowledge concerning farming, and meeting with friends (Figure 3). When we compare how they devote their time to these activities, we can also see the priorities of the farmers.

Source: authors' research

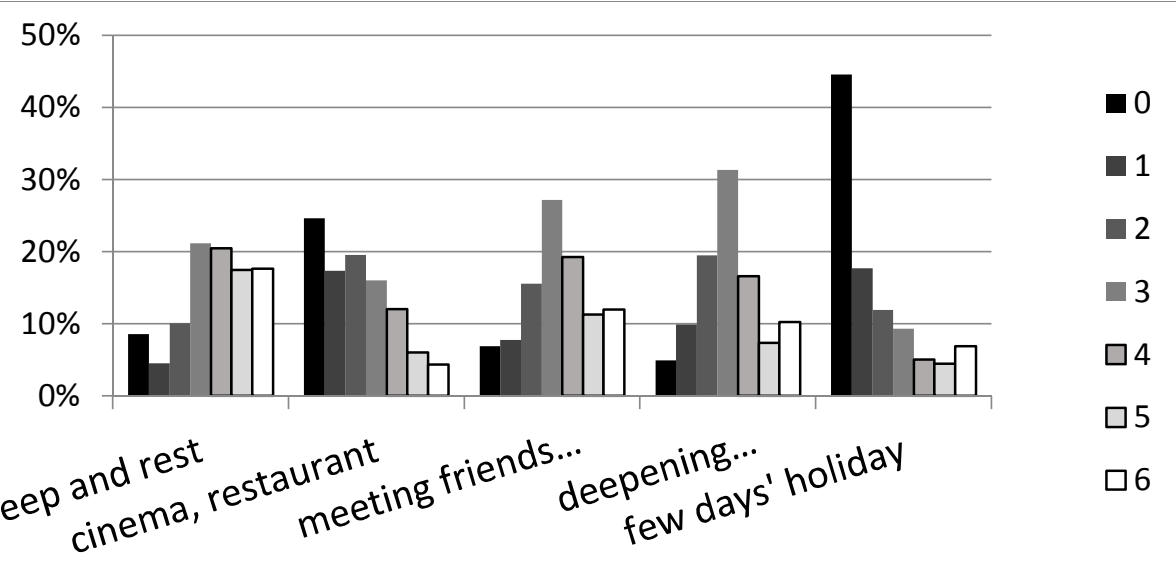

Fig. 3. How do you assess how much time do you have for the following activities? (0- definitely not enough time, 6 - definitely enough time)

We can see that farmers usually have enough time for sleep and rest, the next higher assessments have been assigned to meetings with friends and family, followed by deepening knowledge about farming. It is worrying that as many as $25 \%$ of farmers definitely do not have enough time to go out to a restaurant or to the cinema (about $40 \%$ if we add the second group), and almost $45 \%$ (or $60 \%$ for two lowest answers) do not have enough time for a few days holiday. Problems with keeping the work-life balance was observed also by Hennessy et al. (2013) on a representative sample of Irish farmers. Coming back to Polish sample, it is interesting that at the same moment $3 / 4$ of the respondents declared that they did not need to hire additional workers, while about $9 \%$ could not find appropriate people in the neighbourhood, and $10 \%$ found it too costly. It seems that the farmers, although overworked, do not find it easy to hire additional people. Maybe they are afraid of cooperation with someone outside of the family, or they just do not like changes.

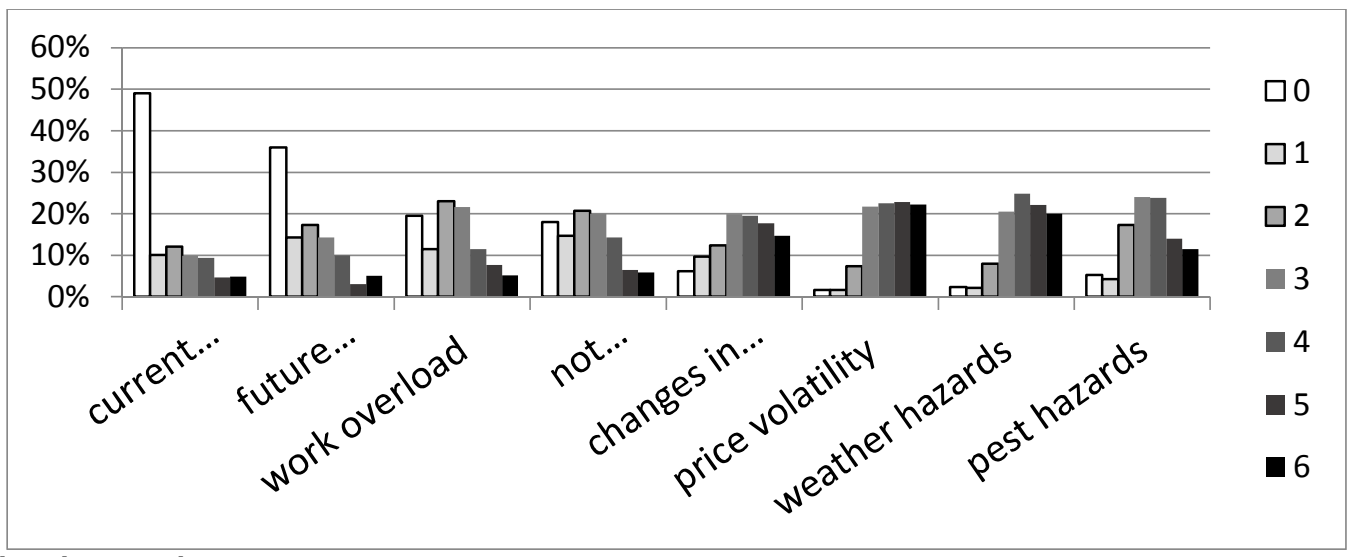

Source: authors' research

Fig. 4. How often do you feel stressed about the following issues? ( 0 - never; 6 - very often) 
Let us now describe the level of stress faced by the farmers (Figure 4). The least stress they feel about their current and future indebtedness (answer "never" was given by $49 \%$ and $36 \%$, respectively). About $1 / 5$ of the respondents felt stressed "very often" by price volatility and weather hazards, followed by changes in law regulations (15\%), and pest hazards (11\%). It seems that the farmers feel less stress when they can manage the risk (such as debts), in comparison with the changes that are beyond their influence (weather, law regulations, market risks).

We wanted to get more information on their understanding of the economy and regulations concerning agriculture (Figure 5).

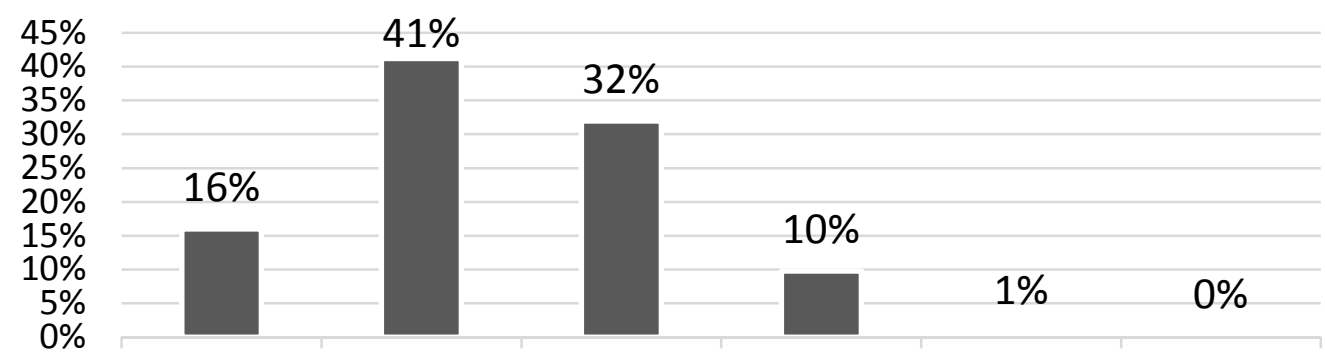

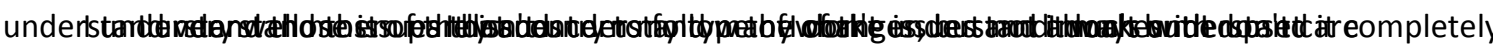
success

Source: authors' research

Fig. 5. How do you assess your understanding of current situation in agriculture and economy (such as prices, single area payments, EU regulations)?

Over $40 \%$ of the respondents declared that they understand the issues that concern their type of production, additional $16 \%$ understand very well most of the regulations. Even if this is only a subjective feeling, they do not feel stress about it. The next $32 \%$ declare that they understand these issues partly and try to follow the changes, but not always with success. $10 \%$ are upset with the fact that they cannot understand the regulations and mechanisms, while almost $1 \%$ understand little, but do not care.

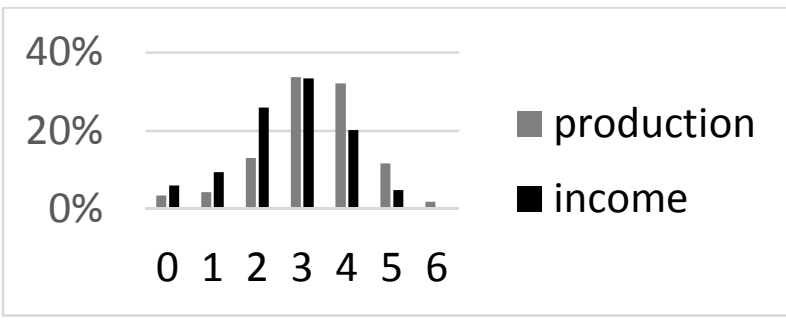

Source: authors' research

Fig. 6. How do you assess the stability of your production and of your income during last few years? ( 0 -very unstable, 6- very stable)

The distribution of stability of production and of income was close to normal, with a bit more stability in the case of production (Figure 6.)

We also checked how much of the stress is connected with the environmental restrictions connected with farming. It came out that only $13 \%$ of the farmers found environmental restrictions easy to implement. As many as $58 \%$ found the regulations important, but troublesome, and as many as $24 \%$ claimed that these regulations should be definitely less restrictive. 


\section{Source: authors' research}

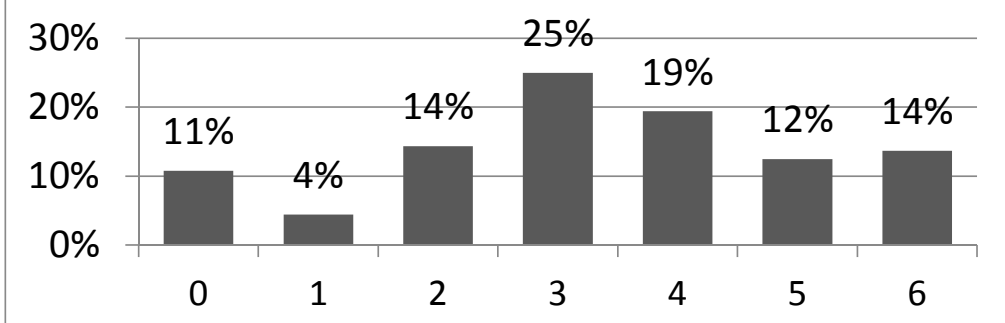

Fig. 7. How useful in your work on the farm is the knowledge you got during formal education? (0 - useless, 6 - very useful)

The assessment of the usefulness of knowledge acquired during education (Figure 7) was supposed to reflect a possible frustration following devoting time to learning issues not used in practice. The distribution was rather even, with a peak in the middle answer, and a bit more votes for usefulness than uselessness of the knowledge.

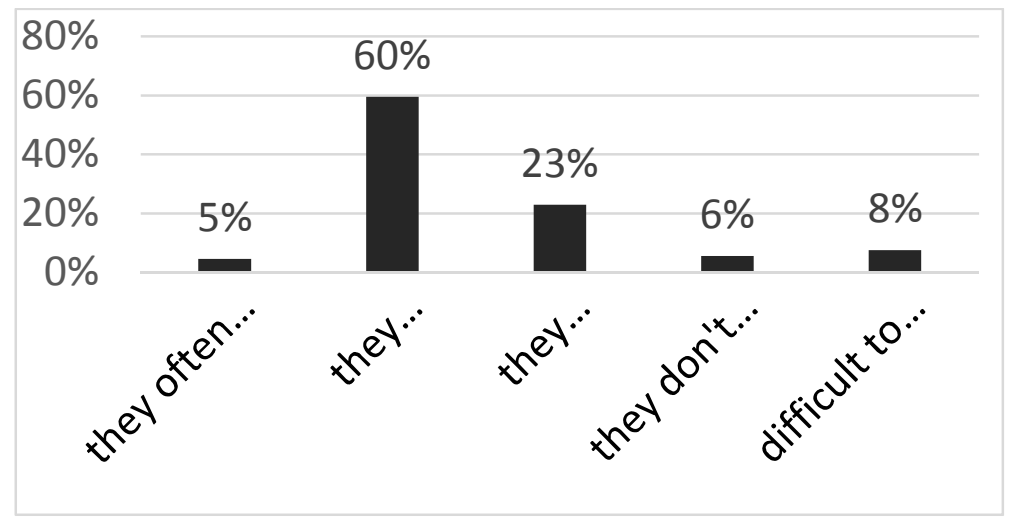

Source: authors' research

Fig. 8. Do people in your village help each other?

As many as $65 \%$ of the respondents could count on help from other villager, if needed, and additional $23 \%$ could receive help „sometimes" (Figure 8).

Table 2

\section{The levels of ",mental comfort" index according to the level of education of the respondents}

\begin{tabular}{|c|r|r|r|r|}
\hline & primary & vocational & secondary & higher \\
\hline Minimum & 0.21 & 0.23 & 0.3 & 0.28 \\
\hline Average & 0.45 & 0.52 & 0.54 & 0.56 \\
\hline Maximum & 0.61 & 0.76 & 0.74 & 0.77 \\
\hline $\begin{array}{l}\text { Standard } \\
\text { deviation }\end{array}$ & 0.105 & 0.09 & 0.092 & 0.094 \\
\hline
\end{tabular}

Source: authors' research

The level of mental comfort was positively correlated with the level of education of the respondents (Table 2). The analysis of variance (ANOVA) revealed that the differences between average indicator of mental comfort depending on the educational level were statistically significant $(p=0.000001)$.

The farmers who chose the answer "cooperating with other people allows for achieving more, than working on your own" scored on average 0.55 , while those who chose "cooperation is usually a waste of time" or "difficult to say" scored on average 0.51 . Those who made the decisions on the farms usually on their own scored 0.51 , while those who did it together with the family and the workers or at least listened to their opinions scored 0.54 and 0.55 , respectively.

As it was written in the beginning, the index of "mental comfort" was, together with an index of live conditions, a part of an aggregated index of social dimension of sustainability. The correlation between 
these two sub-indices was statistically insignificant, which means that including the index of "mental comfort" in the sustainability index allows for including new information in the analyses. We could observe low (from 0.23 to 0.32 ), but statistically significant positive correlations between the index of mental comfort and such indicators of the economic size of the farm, as: farm assets, equity capital, farm income, production value, and the area of agricultural land (this is a result different than obtained in the USA studies, where subjective well-being of the farmers was not significantly correlated with size of the farms (Coughenour, Swanson, 1992). The age of the farmer, number of years in farming or number of years as an independent farm manager were not significant. The farmers who declared that they avoid taking credits or try to keep some cash "for a rainy day" were more likely to receive high grades in the mental comfort index (correlations 0.19 and 0.14 , respectively).

\section{Conclusions}

In the sample, the composite indicator of mental comfort reached levels between 0.2 and 0.77 (with possible range 0 to 1 ), and an average 0.53 . The distribution was close to normal, with a visible majority of the sample in the middle. The index of mental comfort and the index of living conditions were not correlated, which means that including the "mental comfort" in the sustainability index allows for adding new information to the analyses. We could observe low but statistically significant positive correlations between the index of mental comfort and a set of indicators of the economic size of the farm.

As for the parameters included in the index, their distributions depended on particular questions. As we could observe, the farmers are moderately stressed. They feel less stress when they can manage the risk (such as debts), and more when they have No influence on the situation (weather, law regulations, market risks). It seems that the farmers, although overworked, do not find it easy to hire additional people. Most of them are usually able to have enough (or almost enough) rest or meet with friends, but it is difficult for them to leave the farm, especially for few days. It could be a real lack of time or a problem in approach (leaving the farm without the manager).

Over $40 \%$ of the respondents declare that they understand the issues that concern their type of production, additional $16 \%$ understand very well most of the regulations, but $32 \%$ were not able to follow some of the regulations, which made them frustrated. If we take into account that these are only farmers producing for the market (FADN sample), and not subsistent ones, we see that there is a problem - either in the form in which the regulations are presented or in the speed in which they are changing. As many as $58 \%$ found the environmental regulations important, but troublesome in implementing.

The level of mental comfort was positively correlated with the level of education of the respondents. The farmers who chose the answer "cooperating with other people allows for achieving more, than working on your own" had on average slightly higher score, than those who chose "cooperation is usually a waste of time" or "difficult to say". This might be a result of general open-mindedness and belief in other people.

\section{Bibliography}

1. Bacon, C. M., Getz, C., Kraus, S., Montenegro, M., Holland, K. (2012). The Social Dimensions of Sustainability and Change in Diversified Farming Systems. Ecology and Society 17(4): 41.

2. Balbi, S., del Prado, A., Gallejones, P., Geevan, Ch. P., Pardo, G., Perez-Miñana, E., Manrique, R., HernandezSantiago, C., Villa, F. (2015). Modelling Trade-offs among Ecosystem Services in Agricultural Production Systems. Environmental Modelling \& Software, Vol 72, pp. 314-326.

3. Bebbington, J., Dillard, J. (2009). Social Sustainability: an Organizational-level Analysis. In: Dillar, J., Dujon, V., King, M.C. (eds) "Understanding the Social Dimension of Sustainability". London: Routledge.

4. Campbell, H., Fairweather, J., Hunt, L., McLeod, C., Rosin, Ch. (2004). Social Dimensions of Sustainable Agriculture: a Rationale for Social Research in ARGOS. ARGOS Working Paper No. 1.

5. Coughenour, C. M., Swanson, L. (1992). Determinants of Farmers' Satisfactions with Farming and with Life: a Replication and Extension. Southern Rural Sociology, Vol. 9 No. 1, pp. 45-70. 
6. FADN. (2008) Plan wyboru proby gospodarstw rolnych Polskiego FADN 2008 (Plan of Sampling for Polish FADN). Warsaw: IERiGZ-PIB.

7. Galdeano-Gomez, E., Perez-Mesa, J.C., Godoy-Duran, A. (2016). The Social Dimension as a Driver of Sustainable Development: the Case of Family Farms in Southeast Spain. Sustain. Sci. Vol. 11, pp. 349-362.

8. Greiner, R. (2015). Motivations and Attitudes Influence Farmers' Willingness to Participate in Biodiversity Conservation Contracts. Agricultural Systems Vol. 137 pp.154-165.

9. Hennessy, T., Buckley, C., Dillon, E., Donnellan, T., Hanrahan, K., Moran, B.,Ryan, M. (2013): Measuring Farm Level Sustainability with the Teagasc National Farm Survey. Carlow, Ireland: Teagasc.

10. Latruffe, L., Diazabakana, A., Bockstaller, Ch., Desjeux, Y., Finn, J., Kelly, E., Ryan, M., Uthes, S. (2016). Measurement of Sustainability in Agriculture: a Review of Indicators. Studies in Agricultural Economics, Vol. 118, pp. 123-130.

11. Lowrance, R., Hendrix, P. F., Odum, E. P. (1986). A Hierarchical Approach to Sustainable Agriculture. American Journal of Alternative Agriculture. Vol.1, pp.169-173.

12. Mikułl, A., (2016). Zrownowazony rozwoj w krajach Unii Europejskiej - obszar integracji spolecznej (Sustainable Development in the European Union Member States - the Area of Social Inclusion), Konsumpcja i rozwoj, Vol. 1 (14), pp.5-18.

13. Mikula, A., (2017). Sustainable Development of Rural Areas in Poland. Competitiveness of European Agriculture and Food Sectors : Proceedings of the 26th International Scientific Conference, September 13 - 15, 2017 Prague, Czech Republic. - Prague : Czech University of Life Sciences Prague, 2017. - pp. 226-232.

14. Neyman, J. (1934). On the Two Different Aspects of the Representative Method: The Method of Stratified Sampling and the Method of Purposive Selection. Journal of the Royal Statistical Society Vol. 97, pp.558-625.

15. Pearce, D. (1993). Economic Value and the Natural World. London: Earthscan.

16. Raczkowska, M. (2017). Spojnosc spoleczna na obszarze Unii Europejskiej (Social Cohesion in the European Union), Research Papers Of Wrocław University Of Economics No 475, pp.258-269.

17. Reytar, K., Hanson, C., Henninger, N. (2014). Indicators of Sustainable Agriculture: a Scoping Analysis. Instalment 6 of "Creating a Sustainable Food Future". World Resources Institute.

18. Sachs, I. (2011) Trzeci brzeg. W poszukiwaniu ekorozwoju. (The Third Shore. Looking for Sustainable Development). Warszawa: Wydawnictwo Uniwersytetu Warszawskiego.

19.Spindler, E. (2013). The History of Sustainability. The Origins and Effects of a Popular Concept. In: Jenkins,I., Schroder, R. (eds), "Sustainability in Tourism”. Wiesbaden: Springer Gabler.

20.Sulewski, P., Kloczko-Gajewska, A. (2018). Development of the Sustainability Index of Farms Based on Surveys and FADN Sample. Problems of Agricultural Economics. Vol. 3, pp. 32-56.

21. Thompson, P. (2007). Agricultural Sustainability: What It Is and What It Is Not. International Journal of Agricultural Sustainability. 5:1, pp. 5-16.

22.Vehkamaki, S. (2005). The Concept of Sustainability in Modern Times. In: Jalkanen, A., Nygren, P. (eds), Sustainable Use of Renewable Resources - from Principles to Practices. University of Helsinki Department Ecology Publications 34.

23. Was, A. (2013). Modelowanie przemian strukturalnych polskiego rolnictwa (Modelling of Structural Changes in Polish Agriculture). Warszawa: Wydawnictwo SGGW.

24. World Commission on Environment and Development. (1987). Our Common Future. Oxford: Oxford University Press.

25. Wykluczenie i integracja spoleczna w Polsce. Ujecie wskaznikowe, (Social Exclusion and Social Integration in Poland. An Index Approach). Raport, 2006, Warszawa. 